\title{
Epistemology and Embodiment: Diagnosis and the Senses in Classical Ayurvedic Medicine
}

\author{
Lisa Allette Brooks \\ University of California, Berkeley \\ labrooks@berkeley.edu
}

\begin{abstract}
The sensory perceptive capacities of Ayurvedic physicians play a key role in diagnosis. Drawing upon both classical Ayurvedic treatises and field research, this article examines the ways that some contemporary Ayurvedic physicians in Kerala describe their sensory diagnostic abilities in relation to diagnostic techniques of the past and present. These physicians are in a sensory negotiation, first, with diagnostic theory and practice as explained in classical Ayurvedic medical treatises, and second, with contemporary diagnostic technologies that are understood to both extend and attenuate sensory perception. In the course of my historical textual research, I interviewed a number of Ayurvedic physicians who explained their own capacity for sensory perception as limited, in relation to the authoritative teaching of the treatises and the idealized sensory capacities of authoritative individuals (aptas). Their experiences of inhabiting a present, informed by the authority of Ayurveda's textually codified past, and in an evolving relationship with contemporary diagnostic technologies, instantiate a larger narrative that Ayurvedic medicine is in a state of crisis in India. This relationship to knowledge and the senses entails a sensory negotiation converging on the physician's body as a site for the making of truth claims, and for the contemporary practice and experience of Ayurvedic medicine.
\end{abstract}

\section{Keywords}

Ayurveda - diagnosis - epistemology - Indian medicine - senses - sensory negotiation

* First and foremost, I offer a heartfelt thanks to all of the Ayurvedic physicians and students who generously and enthusiastically shared their time, experience, and expertise with me

(C) LISA ALLETTE BROOKS, 2018 DOI 10.1163/22879811-12340027

This is an open access article distributed under the terms of the prevailing CC-BY-NC-ND license at the time of publication. 


\section{Introduction}

An epistemological framework for classical Ayurvedic medicine, found in the Carakasaṃhitā, includes four valid means of knowledge, or pramānas: authoritative teaching (āptopadeśa), sensory perception (pratyakșa), inference (anumāna), and conjunctive reasoning (yukti). ${ }^{1}$ According to this scheme, authoritative teaching is an epistemological foundation of the medical system and is closely linked to the authoritative status of classical Ayurvedic treatises themselves. ${ }^{2}$ For Ayurvedic physicians as represented in the classical treatises, the experience of diagnosing illnesses also relies upon sensory perception combined with inference, and in certain passages, with yukti, as a form of conjunctive reasoning. ${ }^{3}$ The sensory perceptive capacities of Ayurvedic physicians, as mediators of the embodied experience of knowing, play a key role in Ayurvedic diagnosis. Drawing upon my study and translation of classical Ayurvedic treatises and nineteen months of research in India, based in Kerala, this article examines the ways that some contemporary Ayurvedic physicians practicing in Kerala describe their sensory diagnostic abilities in relation to diagnostic techniques of the past and present. These physicians are engaged in what I shall call a sensory negotiation, first, with diagnostic theory and practice as explained in classical Ayurvedic medical treatises, and second, with

over a period of nineteen months in India from 2015-2017. I would like to thank the following people for their valuable comments on my manuscript: my committee members Robert Goldman, Lawrence Cohen, and Alexander von Rospatt, and also M. K. Madan Kumar, Pooja T. Amal, Janet Um, Kathleen Gutierrez, and Alan Brooks. I am deeply grateful to Shrikant Bahulkar and Pooja Amal for reading through my Sanskrit translations and graciously sharing their expertise and insights, and Pradeep Gokhale for our discussion of technical philosophical terms. Special thanks to Dominik Wujastyk for his comments on an abbreviated version of this paper offered at the 3 Societies Conference in Edmonton, Alberta, Canada, in June 2016. I would like to thank the staff of the Kerala Council for Historical Research in Thiruvananthapuram and the Bhandarkar Oriental Research Institute in Pune. I gratefully acknowledge a Fulbright-Hays Doctoral Dissertation Fellowship and the Department of South and Southeast Asian Studies at the University of California, Berkeley for supporting my fieldwork.

1 Carakasaṃhitā, Sūtrasthāna 11.17-25. For a detailed discussion of epistemological models offered in the Carakasamnitā see Preisendanz 2009.

2 This priority is according to the order given in Carakasaṃhitā, Sütrasthāna 11.17-25 as well as sections of Carakasaṃhitā, Vimānasthāna, chap. 4. See also Ashokan 2015, 194.

3 In this context, yukti is a type of reasoning that takes into account multiple interacting causal factors, so I translate the term as "conjunctive reasoning." For discussions of yukti in this passage see Dasgupta, Agarwal, and Jain 1969, 2:373, 375; Filliozat 1990; 1993, 106-109; Preisendanz 2009, 281, 300n104. 
contemporary diagnostic technologies that are understood to both extend and attenuate sensory perception. ${ }^{4}$ In the course of my historical textual research, a number of Ayurvedic physicians explained their own capacity for sensory perception as limited, in relation to the authoritative teaching of the treatises and the idealized sensory capacities of authoritative individuals (aptas). ${ }^{5}$ Their experiences of inhabiting a present, informed by the authority of Ayurveda's textually codified past and in an evolving relationship with contemporary diagnostic technologies, instantiate a larger narrative I repeatedly encountered, namely that in India, Ayurveda is in a state of crisis. ${ }^{6}$ At the same time, physicians skillfully navigated the process of diagnosis with confidence in their dayto-day practice of Ayurvedic medicine.

\section{Epistemological Crisis}

Narratives of the crisis facing Ayurveda revolve around issues practitioners grapple with in the overlapping realms of epistemology and education. But these narratives exist in contrast with the passion physicians I spoke with invariably exhibited for the "science." In his address at the Third Global Ayurvedic Conference in Kozhikode, Kerala, India's Prime Minister Narendra Modi reaffirmed the Indian government's commitment to Ayurveda and suggested that it could play a central role in the World Health Organization's stated mission of combatting noncommunicable diseases worldwide. However, Modi (2016) also named one of the central challenges faced in the "propagation" of Ayurveda as "inadequate scientific scrutiny and concerns regarding standards and quality."

4 See Charles Leslie's $(1992,201)$ discussion of contemporary Ayurvedic diagnosis as a syncretic process based on tacit knowledge. For a discussion of modern Ayurvedic diagnosis centered on the physician's "body-as-technology," see Mukharji 2016a, 227-256.

5 Most often these authoritative individuals were imagined to reside in the past. In some cases, however, they were located in the present and understood to possess special sensory capacities due to a lifestyle and practices that expand their ability to perceive.

6 Langford's ethnographic study of Ayurveda, conducted in the 1990s, identifies a prevalent narrative of "decline" in the practice of the medical system. She explains this narrative as easily "assimilated" into the Indic temporal model that understands contemporary times as the kaliyuga, an era of "darkness" and "adharma" ("unrighteousness") (Langford 2002, 16). One physician explained the crisis of Ayurveda to me in these temporal terms as well.

7 When practitioners referred to "the science" of Ayurveda, they were speaking of the intertwined textual bases and evolving practice of Ayurveda. For a historical treatment of this terminology, see Projit Mukharji's (2016b, 28-30) discussion of the choice of nineteenth-century "Ayurvedists" to label Ayurveda as "science" rather than as "medicine." 
This issue was a central topic of discussion at conferences where members of the Ayurvedic community grappled with questions of research methodology and training. For example, one methodological problem discussed frequently was how to produce research maintaining the case-specific diagnostic and treatment methods of Ayurveda while demonstrating clinically significant and replicable results publishable in scientific journals. ${ }^{8}$ At the same time, in an implicit critique of this agenda, several physicians told me that "authentic" practitioners of Ayurveda are not present in the public eye trying to publish studies or market products. Rather, practitioners of śuddha (pure, authentic) Ayurveda are, for the most part, imagined to operate out of the limelight, far from universities and academic publications, running their own clinics, and often not sharing their teachings with anyone outside of their family lineage. ${ }^{9}$ Dr. P. Ram Manohar, a renowned teacher and leader in reforming Ayurvedic research and education, describes the problem of negotiating these epistemological and methodological problems in the context of Ayurvedic education as follows:

The entire Ayurvedic curriculum is designed in a manner that mimics the м ввS course with a view to achieve equal status with modern medicine. ${ }^{10}$ Even the topics of study are terms translated from English to Sanskrit to create subjects that did not exist in Ayurveda.... There is a need to have a thorough revision of the syllabus and the network of topics that will be effective to convey the thought process of Ayurveda to the student and not end up as a cheap caricature of western medicine.

MANOHAR 2014, 144

8 These debates have been going on for at least the last three decades. See Langford 2002, 140-187.

9 This distinction is congruent with Charles Leslie's (1976, 358-359) categories of Indian medicine from the 1970s, which include (1) classical Ayurveda as outlined in treatises; (2) "traditional-culture medicine" as the syncretic contemporary practice of Ayurveda; and (3) "professionalized Āyurvedic medicine" practiced by those participating in professional associations, conducting research, and teaching in universities, respectively. However, at present, I did not encounter such a sharp divide among practitioners as many of them seemed to inhabit and perform multiple roles as practitioners and teachers. For a discussion of the history and politics of śuddha Ayurveda in the context of twentieth-century revivalism of Indian medical systems see Leslie 1976, 356-367; see also Dominik Wujastyk (2008, 67-68) on the 1963 Vyas Report. 
Manohar's position suggests addressing the crisis in Ayurvedic education through establishing a curriculum that presents classical Ayurveda on its own terms rather than attempting to mold Ayurveda into a form of "modern/ western medicine." Significant steps taken in this direction in Kerala include the creation of residential educational workshops for students that teach the theory and practice of classical Ayurveda through direct engagement with the treatises and the establishment of a new private Ayurveda college modeled on the traditional gurukula training system where students live and study with their teachers for an extended period of years." ${ }^{11}$

Adding to the sense of crisis, however, is the prevalent view held by Ayurvedic practitioners and students that most Ayurvedic medical students are enrolled in the Ayurvedic BAмs (Bachelor of Ayurveda, Medicine and Surgery) training program because they did not gain admission into the preferred allopathic мввS program. ${ }^{2}$ Dr. A, a physician in her late twenties, explained, "The worst part is if you don't get to study anything else-engineering or computer science-if you have the lowest mark, you go into Ayurveda. There are so many people who study Ayurveda but practice allopathy. In Kerala this is bannedin South India it is banned." Her first point was echoed repeatedly by faculty members teaching at Ayurveda colleges and мв вs students. However, a number of the physicians I met had chosen Ayurveda as a vocation either because they come from a family of Ayurvedic physicians or a teacher suggested that career path to them. Other physicians, while not having initially aimed for an мввь as their first choice of degree, became passionate about the study and practice of Ayurveda, having studied with a particular teacher or attended an intensive residential training program as mentioned above.

11 One example of this was was the week-long "Amṛtasūtram" program held at Amṛta Ayurveda College that I attended in August of 2016. The program, attended primarily by advanced BAMs and postgraduate students, taught the thirty chapters of the Aștāñgahrdayasaṃhitā, Sūtrasthāna through the methods of study described in the text itself, pātha (recitation), avabodha (understanding), and anușthāna (practice), with the addition of tadvidyācārya ([exposition by an] expert-teacher), and svādhyāya (self-study). See Aștāñgahṛdayasaṃhitā, Uttarasthāna 40, 82. Ashtamgam Ayurveda Chikitsalayam \& Vidyapeedham was opened in Kootanand, Kerala, in 2016.

12 In this article I use the terms "modern medicine" and "allopathic medicine" to describe what is often referred to as Western biomedicine, and what Dominik Wujastyk calls "modern establishment medicine," because these are the terms most widely used by the physicians I worked with. The prevalent use of the label "modern medicine" reveals a tension in the way that practitioners of Ayurveda perceive their relationship to this "traditional" form of medicine as they negotiate its practice and existence in the "modern" world. See Wujastyk 2011a. 
As Dr. A. notes, in Kerala, it is illegal for Ayurvedic practitioners to practice allopathic medicine, whereas in Maharashtra, for example, many BAMs graduates practice a combination of allopathic medicine and Ayurveda. ${ }^{13}$ While an Ayurvedic physician in Kerala can order diagnostic laboratory tests such as blood sugar and cholesterol screening, or imaging, such as X-ray or MRI, they are not legally permitted to prescribe allopathic medicines or to perform allopathic procedures. Physicians did not report frequently ordering diagnostic tests, though laboratory tests were ordered-for example, the "urine routine examination" that enables assessment of kidney function and detection of diabetes. ${ }^{14}$ Dr. K., a physician in his mid-thirties, explained that this was not a diagnostic test, but rather, a "pre-clinical" test to assess the patient's kidney function and make sure they are not experiencing renal failure, because if a patient's kidneys are not functioning within a normal range then the Ayurvedic medicines will not work properly. He also orders pre-clinical urine tests to protect his own liability against claims of kidney damage caused by the possible heavy metal content of some Ayurvedic medicines, an issue that has received considerable media attention in the past decade (e.g., Khandpur et al. 2008; Rai et al. 2008). The two main physicians I worked with asked almost every patient if they had the results of recent blood sugar and cholesterol tests. If a patient brought diagnostic tests ordered by allopathic doctors to their Ayurvedic consultation, a common occurrence, the physician had to be able to read, understand, and converse with the patient about them. Establishing credibility in the eyes of patients and integrating different types of knowledge into diagnosis are twin challenges faced by Ayurvedic physicians practicing in a medical landscape dominated by "modern" medical epistemology.

\section{Epistemology and Embodiment}

The vitality and importance of the classical treatises to the practice and embodied experience of physicians was readily apparent in clinical practice. This is not to say that practices described in the classical treatises were precisely followed, but that physicians considered the classical treatises as a central basis of their practice and often referred to them in discussion. ${ }^{15}$ In Kerala, this was

13 For a study on the prevalence of allopathic medical practice among practitioners of traditional medicine in Ahmednagar district Maharashtra, see Sule and Kavadi 1993.

14 The "urine routine examination" is also known as a routine urine test or urinalysis.

15 On the relationship between textual knowledge and a specific enema practice in contemporary Kerala, see Sankaranarayana 2013. 
particularly the case with the Aștāngahrdayasamnhitāa, a treatise written as an easily memorized physicians' manual that is the most widely used classical Ayurvedic text in the state. ${ }^{16}$ Classical treatises were ubiquitously present on bookshelves and desks, and physicians referred to them when speaking publicly and in informal conversations. Although I set out to study touch in classical Ayurveda of the first millennium, ${ }^{17}$ the issue of perceived sensory limitation in contemporary diagnosis emerged repeatedly in conversations and interviews about touch in classical Ayurvedic philosophy and practice, becoming a topic of research in and of itself. The field research portion of this study is based on attending over two hundred hours of patient consultations in three urban clinics in Kerala during the course of textual study sessions, informal interviews with nine Ayurvedic physicians and conversations with numerous Ayurvedic physicians, teachers, and students, ${ }^{18}$ visits to Ayurvedic clinics and hospitals, ${ }^{19}$ and attendance at two academic conferences and one week-long intensive residential training course on Ayurveda. The physicians whom I interviewed were all BAMs graduates; eight of them also had earned an advanced postgraduate MD degree (Ayurveda Vachaspati), ${ }^{20}$ five of them came from families with a tradition of Ayurvedic practice, and out of this last group, two also received traditional training in a gurukula setting. All of the physicians practiced in or within fifteen miles of an urban area, and most worked in more than one location. They worked in a range of settings, including inpatient and outpatient faculties at large private Ayurvedic hospitals, and self-owned small and medium-sized home clinics. Two of the physicians had founded large Ayurvedic centers, and half were teaching, or had taught, at a public or private Ayurvedic college. ${ }^{21}$

16 Different texts are used by physicians on regional and local bases; for example, in Pune the Carakasamhitā was the primary reference text used at the clinics I visited.

17 This is the topic of my forthcoming dissertation at the University of California, Berkeley, "Translating Touch in Âyurveda."

18 Conversations and interviews were recorded through handwritten or typed notes; language that I transcribed verbatim appears here in quotation marks, with the exception of the occasional verbal form or prepositional phrase changed to ease the reader's understanding.

19 The places of practice I visited ranged from a consultation office in a family residence to outpatient clinics and inpatient hospitals.

20 Most physicians indicate this designation on their business cards and signs as "M.D. (Ayurveda)."

21 To maintain the anonymity of Ayurvedic physicians, identifying factors have been omitted and names have been shortened to a single letter. For this reason, I have not noted the caste, religion, or political affiliation of physicians although these are important axes of identity in contemporary Kerala. 
Dr. B, an Ayurvedic physician in his late twenties who came from a family of Ayurvedic practitioners, explained his relationship to his father's practice and to the broader landscape of contemporary medical practice in Kerala today: "[Our] personal practice is the same-the major difference-I had a little more exposure to the modern world so ... not using modern diagnostic techniques, but little concepts I'll share with this modern world." Dr. B.'s emphasis is on the fact that, like his father, he does not appropriate "modern" diagnostic techniques, however, he does share aspects of Ayurveda with the "modern world." While physicians are frequently faced with laboratory test results and diagnostic imaging in the course of patient consultations, some find this problematic, not only in relationship to their ideals around the practice of Ayurveda, but also in their experience of their own bodies and diagnostic sensory capacities. As Dr. B. explained,

For each thing there is a domestic and a wild version, the buffalo, the elephant [the list included several more examples], but not the duck. Each and everything is domesticated and wild. There are not wild ducks, domesticated only. Is it not? The same thing happens to humans. You are using CT. You are using MRI. You are losing your power. The same thing is happening with antibiotics. You give antibiotics, your immune system won't get a chance to do the work and develop. The same is true of digestive enzymes, your enzymes won't be produced in your stomach.

After revealing his anxiety about losing his power of perception through domestication, Dr. B. continued to reveal a tension in his position. "We have MRI. We have CT scan. We know what is happening in the body. In Ayurveda we have [had] this system for 3,000 years, yes, with no upgrading. Because of egos humans are losing." Dr. B. is simultaneously concerned with losing his capacity to sense and also with the practice of Ayurvedic medicine in the present and what it might be losing by not "upgrading," in the sense of adapting Ayurveda in a manner that retains its unique capacities while evolving in its encounters with allopathic medicine. Explaining the use of these diagnostic techniques, Dr. B. revealed a further complication: "You get 20 percent commission for any procedure. For some things you need the help of modern diagnosis." Yet he distanced himself from this practice stating,

Only once in my life I wrote a CT scan-for a small child. That is the only case I have used some modern diagnosis. Most of the cases I can get. I can diagnose without seeing a diagnosis. You can guess about it. In Ayurveda they tell about using yukti. After learning about techniques, [learning] 
about the body (he listed Ayurvedic components of the body) ... after a long time you can diagnose correctly.

It is in this space of reasoning, yukti, performed on the basis of authoritative knowledge, sensory perception, and one's own practical experience, that Dr. B. performs diagnosis and practices Ayurveda in the face of competing epistemologies.

The Ayurvedic physician's embodied experience of diagnosis necessarily entails a sensory negotiation between disparate epistemologies crystallized in the form of the authoritative knowledge of treatises and technologies. Sensory negotiation is enacted in the field of what Lorraine Daston and Peter Galison $(2007,40)$ call "epistemic virtues," internalized norms around effective means of knowledge and the forms of "disposition" that facilitate knowing. Illustrating the enmeshment of epistemology and embodiment, Daston and Galison's work on scientific objectivity shows that striving toward these norms results in the production of types of "scientific selves" (44), or in Foucauldian terms, forms of subjectivation through "technologies of the self" (233). ${ }^{22}$ They demonstrate that different epistemic virtues can exist at the same time, competing, coexisting, and modifying one another (Daston and Galison 2007, 44, 199), "[b]ut although they may sometimes collide, epistemic virtues do not annihilate one another like rival armies. Rather, they accumulate" (363). In contemporary Kerala the epistemic virtue of authoritative testimony as a means of valid knowledge-idealized in the figure of the authoritative individual (apta) possessing a cultivated mind, free from faults-exists simultaneous to the epistemic virtues of "modern" scientific objectivity and trained judgment. Sensory negotiation takes place as the Ayurvedic physician navigates the terrain of this accumulation.

\section{Valid Means of Knowledge, Diagnosis, and the Senses}

Classical Ayurvedic diagnosis is based on the four valid means of knowledge, pramānas, which encompass both the methods of gathering information and the means of processing information. In this section of the paper, after providing a brief introduction to classical Ayurveda, I examine aspects of diagnosis

22 Although Michel Foucault's earlier work addressed technologies of power in relation to subjectivation (i.e., disciplinary power and biopower), his later work turned increasingly to "care of the self" and "technologies of the self" engaging with the relationship between the subject and truth. See, for example, Foucault et al. 2005. 
as described in two classical Ayurvedic compendia with a focus on the sensory experience of the physician. ${ }^{23}$ This is followed, in the next section, by a discussion of the ways that Ayurvedic physicians in Kerala describe their own diagnostic sensory capacities. I suggest that while there is not always direct reference to the epistemological framework set forth in the treatises, the ways that physicians describe their experience of sensory limitation and their anxieties about the use of "modern" diagnostic technologies reflect the critical relationship between the ideal of authoritative teaching - both described in, and represented by, the classical treatises - and the physicians' own sensory perceptions.

Ayurveda is a system of medicine codified on the Indian subcontinent in a series of compendia roughly dating from the second century вСЕ through the seventh century CE. ${ }^{24}$ It is one of seven healing systems recognized by India's Ministry of Ayush along with Unani, Siddha, Sowa Rigpa (Tibetan Medicine), Homeopathy, Naturopathy, and Yoga (Ministry of Ayush 2002). I use the designation "classical Ayurveda" in this article to refer to the medical system set forth in the treatises selected as the brhattrayi, "great threesome," of Ayurveda, and to contemporary practice of Ayurvedic medicine that recognizes itself as based upon these compendia: the Carakasamnitāa, the Suśrutasamnhitāa, and either Vāgbhața's Aștāngahrdayasaṃhitā or Aștāngasaṃgraha. ${ }^{25}$ There are a number of other treatises from this time period as well as the subsequent centuries that are regarded as part of the classical corpus but they are not

23 All translations are mine. When the romanized Sanskrit of translated passages is rendered in the footnotes, I have removed romanized punctuation added by the editors of the published texts but left a single danda (staff mark) to indicate sentence endings and double danda to indicate section breaks.

24 Although there were various schools of medicine present in the first millenium, Dominik Wujastyk $(1997,2)$ explains, "Both the Caraka Saṃhitā and the Suśruta Saṃhitā emanate from a single tradition of medicine, that is, their general views and doctrines are in consonance, and the theoretical basis of medicine presented in the texts is identical." Dagmar Wujastyk (2012) argues that there was a unified system of medical ethics outlined in the texts of that period. Here, I am calling Ayurveda "a system of medicine," with recognition that there were differences in the early schools of general and surgical medicine, as attested in the Carakasaṃhitā and Suśrutasaṃhitāa, respectively (a topic that is part of my current research), as well as of variations in Ayurveda as it evolved over time.

25 According to the current BAMs syllabus set by the Central Council of Indian Medicine (ссім n.d.), the Aștāingahrrdayasaṃhitā is the third of the brhattrayı̄. When one of my colleagues was undergoing BAMs training in the early 2000s, instead, the Aștāingasamgraha was listed on the syllabus as the third member of the brhattrayit. 
addressed here. ${ }^{26}$ The Carakasamnita $\bar{a}$ is a voluminous general medical treatise covering aspects of Ayurvedic philosophy and practice with mixed prose and verse sections. The treatise is thought to be based on an earlier work called the Agniveśatantra, compiled, modified, and added to by Caraka sometime in the first two centuries CE. In the fourth or fifth century CE Dṛdhabhala further redacted the treatise and added several sections, ${ }^{27}$ and in the seventh or eighth century, commentator Jajjața also made editorial contributions to the text (Zysk 2009, 98). The Suśrutasaṃhitā is a similarly long and varied treatise with a special focus on surgical techniques that I will not address in detail in this paper. The works attributed to Văgbhața are based upon the Carakasaṃitā and Suśrutasaṃhitāa, with the Aștāingahrdayasamhitā composed in verse in the short and prescriptive style of a practitioner's manual. Each of these compendia is divided into sections called sthānas.

The study of these treatises in Sanskrit is part of the Ayurvedic curriculum set by the Central Council of Indian Medicine under the Ministry of Ayush in New Delhi. Students in Kerala generally study them aided by Malayalam transcriptions and translations of the treatises along with commentaries written in Malayalam, ${ }^{28}$ and more recently, guided by English translations. As Anthony Cerulli $(2009,271)$ notes, most BAMS students do not have time to attain proficiency in Sanskrit due to lack of training at the primary and secondary school levels. The physicians I met had a range of literacies in Sanskrit. The few having a high level of proficiency had received Sanskrit instruction prior to their BAMS entrance and some had completed a three-year postgraduate MD (Ayurveda) with the specialization of Saṃhitā and Siddhānta, ${ }^{29}$ entailing a close reading of the Carakasamnitā and other classical texts with commentaries for several hours per day. More commonly physicians were able to read, discuss, and recite specific verses from the classical treatises that they had memorized

26 Notable among these are the Kaśyapasamnitā, the Bhelasaṃitā, and the laghutrayī, "little threesome," comprising the Mādhavanidāna, the Śärígadharasaṃhitā, and the Bhāvaprakāśa.

27 For a detailed survey of scholarship addressing Dṛ̂habhala's contribution to the Carakasaṃhitā, see Meulenbeld 1999, vol. 1A. See also n. 77 below.

28 For example, Thirumulpad 2014; Vaidyan 2015; and multi-volume editions of the Carakasaṃhitā and Suśrutasaṃhitā with translation and commentary by M. Narayanan Vaidyar. Vaidyar's editions of the Carakasamnhitā were published in 1979 by the Dhanvanthari Printing Press in Kuttikkalam, Etakkad, and reprinted at Redstar Offset Printers in Calicut in 2009-2011.

29 The BAMs degree is a five and a half year program including a one-year clinical internship. The next level of training for Ayurvedic physicians is the MD (Ayurveda), a three-year postgraduate training in an Ayurvedic specialty. 
during their BAMS training. Important for our purposes is that physicians regarded the classical texts as the ideal basis for their diagnostic practices. Here, I will briefly touch upon diagnosis as described in the Carakasamhitā and the Asțāngahrdayasamhitā, as the former is considered the foundational treatise of Ayurveda and the latter is the most popular and widely used treatise in Kerala.

\section{Diagnosis in Classical Ayurveda}

In classical Ayurveda, diagnosis is a process intertwined with treatment and oriented toward assessment of constellations of multiple properties, or gunas, ${ }^{30}$ represented through humors, doșas, which cause disease when in a state of imbalance. The three doșas, vāta, pitta, and kapha or śleșman, often translated as "wind," "bile," and "phlegm," respectively, are an important element in the conceptual basis for Ayurvedic diagnostics and therapeutics. ${ }^{31}$ In a state of equilibrium they are understood to be physiological constituents, whereas in a state of imbalance they are considered as pathological agents. ${ }^{32}$ In the classical treatises the doșas are described based upon their gunas, and the two

30 See Table 1 and Table 2. The twenty gunas discussed here are a set of properties pertaining to the five elements included in a broader list of guṇas in Carakasaṃhitā, Sütrasthāna 1.49: "[Along] with the [five] sense objects—-heavy,' etc., buddhi, those ending with prayatna, 'para,' etc.-are guṇas" (sārthā gurvādayo buddhị̣ prayatnāntāh parādayaḥ guṇāh proktāh). As Dasgupta notes, this list does not provide an enumeration or precise specification of its contents, but seems to be referring to extant lists of gunas known by the treatise's author. See Dasgupta, Agarwal, and Jain 1969, 1:281. Cakrapānidatta glosses the list as including five sense objects; twenty properties pertaining to the five elements-heavy, etc.; buddhi; a list of properties of Self (ätman) ending with effort (prayatna) (attributed to Carakasaṃhitā, Śärīrasthāna 3.10); and a list beginning with para, etc. (correlating to a set of properties essential to treatment in Carakasaṃhitā, Sütrasthāna 26.31-35). It is the twenty properties pertaining to the five elements that concern us here, and I refer to this subset as the gunas. See Table 1.

31 Here, I retain the Sanskrit terms for the doșas, vāta/vāyu, pitta, and śleșman/kapha becasue translating them simply as wind, bile, and phlegm obscures the complex concepts that these terms designate. For example, in the Aștängasamgraha, the doṣas are described through their elemental composition. Sütrasthāna 20.2 explains that vāyu comprises wind $(v \bar{a} y u)$ and space $(\bar{a} k \bar{a} s ́ a)$, pitta is related to fire (āgneya), and śleșma comprises water (ambhas) and earth (prthivī). Thanks to Pooja T. Amal for assisting me in locating this reference.

32 For a discussion of the early historical development of these concepts in relation to the doșas, see Scharfe 1999. 
main physicians I worked with were both emphatic that the central operating principle in Ayurvedic diagnosis is the gunas. ${ }^{33}$ Diagnosis based on the gunas provides more nuance than simply assessing the doșas, because while each doșa is represented as comprising a specific set of gunas, the latter may occur in different proportions or levels in specific situations. These two physicians described the common process of diagnosis as using an assessment of doșas, tissues (dhätus), and waste products (malas) as primary diagnostic tools, but characterized the gunas as the most accurate means of diagnosis. Guna-based diagnosis works through identification of the gunas causing illness and then providing counteracting and balancing properties in the form of medicine and lifestyle prescriptions. Though in many cases diseases are given names, ascertaining the name of the illness is not the core aim of diagnosis. Carakasamhitā Cikitsāsthāna 30.292 states that whether or not a disease is named in the treatise it can be treated if the cause of disease is understood. ${ }^{34}$ Similarly, the Aștāingahṛdayasaṃhitā, Sūtrasthāna 12.64 exhorts physicians not to feel shame (na jihrīyatt) if they are not knowledgeable regarding the name of a disease, as there is no firm establishment of all diseases by name..$^{35}$ Most named diseases, for example, jvara (fever) or kāsa (cough), have a number of variations based on the gunas as they aggregate in the doșas, vāta or vāyu, pitta, and śleșman or kapha, which then combine with one another to create variants of diseases.

\section{Diagnosis in the Aștāñgahṛdayasaṃhitā: Properties (guṇas) and Perception}

Although the Carakasamnhitā is historically prior to the Aștāngigahrdayasaṃhitā, I begin here with the Aștāingahrdayasamhitā and then move to the Carakasamnitā because this was how the material unfolded in the course

33 For descriptions of the doṣas based on the twenty guṇas see Carakasamhitā, Sütrasthāna 1.59-61 and Aștāàgahṛdayasaṃhitā, Sūtrasthāna 1.11-12. Suśrutasaṃhitā, Sūtrasthāna 6-13 explains the properties of the doșas in a section of the chapter on the treatment of wounds describing the abodes of the doșas. This latter passage, however, is starkly different from the passages in Carakasamhitā and Aștāingahrdayasaṃitāa, as blood (rakta) is included as a doșa and the description of vāta does not contain a list of its gunas. doṣadūṣyanidānānām viparītạ̣ hitạ̣ dhrūvam / uktānuktān gadān sarvān samyagyuktam niyacchati//This passage is found in a section of the text that is attributed to Dṛ̣habala. See Meulenbeld 1999, 1A:130-141. vikāranāmākuśalo na jihrīyāt kadācana / na hi sarvavikārānāạn nāmato 'sti dhruvā sthitih // 
of my discussions with physicians. When speaking with physicians in Kerala about touch in classical Ayurveda, initially they almost invariably cited the diagnostic maxim of trividhaparīks $\bar{a}$ ("threefold examination"),, darśanasparśanapraśnaih ("by means of sight, touch, and questioning"), the beginning of Aștāingahrdayasaṃhitā, Sūtrasthāna 1.22. This text, comprising instructive and clear verses, is a basis for Ayurvedic training and practice in Kerala. Perhaps as a reflection of the pedagogy experienced by practitioners during their Ayurvedic training, the clear diagnostic system of the Asțāngahṛdayasamnitā was usually explained first, followed by the Carakasam hitā, rendering the material more accessible. So I replicate that order here.

The Asțāngahrdayasamhitā is divided into six sections (sthānas), and the initial description of how a physician should examine a patient is found in the first chapter of the first section. This passage, Aștāingahridayasaṃhitā, Sütrasthāna 1.22, follows an exposition of the basic concepts of Ayurveda: the transmission of the teachings; an enumeration of the eight branches; a naming of the three doșas with their respective primary locations (sthānas); times (kälas) (both season and time of day); relations to digestive fire (agni) and to the digestive tract (koștha); an enumeration of the six tastes (rasas); a description of the types of substances and their gunas; a discussion of the causes of disease and health; and definitions of physical and mental disease. Then the treatise turns to diagnosis:

One should examine the patient by means of seeing, touch, and questioning; and the disease, by primary cause (nidāna), ${ }^{37}$ premonitory symptom

$3^{6}$ There are a number of different enumerations of examination (parīsșa $\bar{a}$ in classical Ayurvedic treatises, including two threefold examinations in the Carakasamnit $\bar{a}$-one corresponding to that found in the Așțāngahrdayasaṃhitā, Sütrasthāna 1.22 (Cikitsasthāna 22.25) and another corresponding to the first three pramānas (Vimānasthāna 4.3-7), a fourfold examination corresponding to all four pramānas (Sūtrasthāna 11.17), and a tenfold method of examination based on pratyakșa and anumāna (Vimānasthāna 8.83-84). An eightfold examination method commonly cited by physicians in Kerala is found along with a sixfold scheme in the eighteenth-century pharmacological text, the Yogaratnākara. Meulenbeld 1999, 2A:262. For a charting of these systems see Ranade and Kuber 2010.

37 The term nidana is understood in this verse as one aspect of diagnosis, the examination of primary cause, or etiology. Nidāna can also be used to denote the entire diagnostic process, as in the title of the third section of the Aștāingahridayasaṃhitā, the Nidānasthāna. 
(prāgrūpa), symptom (lakșana ), suitability of food, medicine, and conduct (upaśaya), ${ }^{38}$ and progression $(\bar{a} p t i) \cdot{ }^{39}$

The physician is instructed to use three senses, sight, touch, and hearing, to examine the patient and then to assess the disease through the fivefold method outlined in the second half of the verse. Implicit in questioning patients is listening to their answers through the sense of hearing and then using inference to process the information. According to this system, diagnosis is often not a linear process or one-time event, rather, it unfolds and repeats as the physician uses the threefold examination repeatedly to assesses the effects of food, medicine, and lifestyle practices, and to observe the progression of disease in the patient, adjusting treatment accordingly.

In his Sarvāngasundarā, thirteenth-century commentator Arunadatta explains the physician's experience of diagnosis as centrally concerned with assessing the twenty gunas and therefore reliant upon the senses. ${ }^{40}$ As G. Ashokan notes in his discussion of sensory perception in the Carakasamnhitā, "In cognizing an object all that is directly known by the senses is its qualities."41 The gunas in the Aștāingahrdayasam hitā are a set of twenty properties, or qualities, explained as ten gunas with their opposites, with the complete list of ten pairs constellating to manifest in the doșas (See Tables 1 and 2).

38 As a method of Ayurvedic diagnosis, upaśaya (fr. upa $\sqrt{s} \bar{c}$, "to be suitable or useful") is a technical term referring to the wholesomeness of food, medicine, and conduct in the treatment of a disease. It is often coupled with anupaśaya, referring to unwholesomeness in relation to a disease.

39 darśanasparśanapraśnaih parīkșeta ca rogịnam / rogạ̣ nidānaprāgrūpalakșaṇopaśayāp tibhị̣ // Aștāñgahrrdayasaṃhitā Sütrasthāna 1.22. In the Nidānasthāna we find the term samprāpti, which is usually translated as "pathogenesis," so here āpti is understood as the progression of the disease through different pathways to various locations.

$40 \quad$ Meulenbeld 1999, 3:662-664.

41 Ashokan $(2015,203)$ is translating gunas as "qualities." 
TABLE 1 The twenty properties (guṇas) listed in Aștāngahṛdayasaṃhitā, Sūtrasthāna 1.18 organized as pairs of opposites ${ }^{\mathrm{a}}$

\begin{tabular}{|c|c|}
\hline heavy (guru) & light (laghu) \\
\hline dull (manda) & sharp $(t i ̄ k s ̣ n a)$ \\
\hline cold (hima) & hot (uṣna) \\
\hline unctuous (snigdha) & dry (rūkṣa) \\
\hline smooth (ślakṣna) & rough (khara) \\
\hline dense (sāndra) & fluid (drava) \\
\hline soft $(m r d u)$ & hard (kațina) \\
\hline stable (sthira) & mobile $($ cala $)$ \\
\hline subtle (sūkșma) & gross $($ sthūla) \\
\hline clear (viśada) & slimy (picchila) \\
\hline
\end{tabular}

a Across the classical Ayurvedic texts there is variance in the terms used to name the properties (gunas), the order given, and the way that they comprise the doșas. For example, Carakasaṃhitā, Sūtrasthāna 25.36 names sāra rather than cala and orders the pairs differently.

TABLE 2 The doṣas in terms of the five elements (pañcamahābhūtas) from Așțāingasamgraha, Sūtrasthāna 20.2 and properties (guṇas) from Așțāngahṛdayasaṃhitā, Sūtrasthāna $1.11-12$

doṣa elements (pañcamahābhūtas) properties (guṇas)

vāta (anila) air $(v \bar{a} y u)+$ space (ākaṣa) rūkșa, laghu, śîta, khara, sūkșma, cala pitta fire (agni) sneha, tīkșna, uṣna, laghu, visra, sara, drava kapha earth (prthivì) + water snigdha, śìta, guru, manda, ślakṣna, (ambhas) mrtsna, sthira

The gunas are central to the assessment conducted by the physician and in terms of considering the proximate causes of disease (nidāna), as evident in Arunadatta's explanatory gloss of Sütrasthāna 1.22 which draws heavily upon Așțāngasaṃgraha, Sūtrasthāna 22.11. 
Arunadatta: The patient (lit. diseased, $\operatorname{rog} \bar{\imath}$ ), is one who has a disease, one possessing illness (vyädhita). One (the physician) should examine the patient (tam) by means of sight (darśana), etc. Darśanena means "by sight," [one should examine], with respect to those sick with cough, urinary disorder, etc., yellow and white color, form (samsthāna), measurement, accumulation, complexion (chāya), feces, urine, vomit, etc. ${ }^{42}$ Sparśanena means, "by touching of the body by the hand," one who is sick with fever, a mass (gulma) or abscess (vidradhi), etc., and also, [he should examine] touch (sparśa) of coldness, heat, stiffness, throbbing, softness and roughness, etc. And praśnena, "by asking," means he should examine via the articulation of the patient, the state of pain (śülya), loss of appetite (arocaka), vomiting (chardi), heart palpitation (hrdardatva), positive or negative attitude, soft or hard stools, dreams, intention (abhiprāya), constellations during the onset of disease and at birth (janmämayapravrttinakșatra) ${ }^{43}$ aversion, inclination, happiness, and sorrow. He should examine the disease with those five, nidāna, etc. ${ }^{44}$ Nidāna, kāraṇa, [and] hetụ are synonyms of cause. And this [cause] is twofold divided into proximate (äsanna) and distant (viprakrșta). Proximate cause is also twofold, close (āsanna) and very close (atyāsanna). Close [acts] by the usage of substances that are rough, light, cold, etc. But, that which is very close, causes disease immediately (samanantaram eva). In such a way, the doșas, vāta, etc., are increased. ${ }^{45}$

In this passage, yellow and white color (varna) refer specifically to the hue of bodily consitituents and products, whereas complexion (chāya) is a designation including sets of five qualities attributed to each of the five elements. For example, complexion related to earth is firm (sthira), oily (snigdha), thick (ghana), smooth (ślakșna), brown (śyäma), and white (śveta) (Carakasaṃhitā, Indriyasthāna 7.10-13 and Aștāñgahrdayasaṃhitā, Śärīrasthāna 5.48). Thanks to Hanudha N. K. for explaining this distinction.

43 Arunadatta lists nakșatras (constellations or asterisms) at the time of onset of the disease or at the time of birth as possible astrological causes of disease to be examined through questioning the patient. Much of his commentary on this section is derived from Aștāngasamgraha, Sūtrasthāna 22.11. Due to the unclear meaning of janmāmayapravrttinakșatra, which is not glossed in Indu's commentary, my interpretation of this phrase has followed the translation of Aștāingasaṃraha, Sütrasthāna 22.11 offered by K.R. Shrikanthamurthy $(1995,1: 405)$. In other editions this passage is listed as 22.23. See Aștāingasañgrahạ̣ 2012; Meulenbeld 1990, 1A:500.

44 This refers to the set of five diagnostic methods mentioned in Aștāngahṛdayasaṃhitā, Sūtrasthāna 1.22, nidāna, prāgrūpa, lakșaṇa, upaśaya, and āpti.

45 Note that whereas the "close" proximate cause acts on one or two properties (gunas), the "very close" proximate cause acts on a constellation of properties (gunas) in the form of a doșa. 
Here, Arunadatta emphasizes the importance of the physician's examination of the gunas, such as "coldness, heat, stiffness, throbbing, softness, and roughness," particularly in reference to touch (sparśa). Physicians also indirectly examine gunas through questioning the patient, for example, when assessing the texture of the stool. In his explanation of the distinction between "close" and "very close" proximate causes of disease, Arunadatta also highlights the gunas, explaining that in the case of a "close cause," the disease is caused by one or two gunas interacting via substances coming into contact with the patient. In the case of a "very close" cause, an entire constellation of gunas, in the form of a doșa, is increased.

In the Aștāngahrdayasamnhitā, Nidānasthāna, diagnosis is focused on the fivefold method given in the second half of Sütrasthāna 1.22, translated above. The Nidānasthāna comprises sixteen chapters: an introduction outlining the fivefold method, followed by subsequent chapters explaining the diagnosis of one or more types of illness. The doșas play a central role in the explanation of diagnosis given in this section of the Aștāingahrdayasam hitā as each discussion of the symptoms of diseases (lingas or rüpas) describes the symptoms of diseases arising from vāta, pitta, kapha, and from all three together (samnipāta). In the case of fever (jvara), further variations are given in the form of combinations of two doșas. For a number of illnesses, symptoms arising from other causes are also listed; for example in the discussion of hemorrhoids (arśas), the symptoms caused by vitiated blood (rakta) are detailed. Although the Nidānasthānas of both the Aștānigahrdayasamnhitā and Carakasaṃhitā are organized by type of disease, it is not enough to recognize and name the disease; the physician must understand the underlying causes of the disease in order to diagnose and formulate a treatment.

rogo 'syāstīti rogī vyādhitaḥ tạ̣ darśanādibhị parīkșeta / darśanena drștyā kāsamehādyārteșu pütaśuklavarṇasaṃsthānapramāṇopacayacchāyāvinmmūtraccharditādi kam / sparśanena hastakāyasparśena jvaragulmavidradhyādyārtam tathā śitoṣnastabdha spandaślakṣnakharasparśädikam ca / praśnena pṛcchayā śülārocakacchardihṛdardatvam succhandaduśchandatvam mṛdukrūrakoșthatāṃ svapnadarśanam abhiprāyam janm āmayapravṛttinakșatradvișțeștasukhaduḥkhāni ca ityāturamukhāt parīkșeta / rogam nidānādibhị̣ pañcabhị parīkșeta / nidānaṃ kāraṇam hetur ityanarthāntaram / tac cāsannaviprakrșțabhedena dvidhā / āsannam api dvividham āsannātyāsannabhedena / āsannam rūkṣalaghuśitādidravyopayogaḥ / atyāsannạ̣ tu yataḥ samanantaram eva rogotpattị / yathā vātādayo doșāḥ kruddhāh / 


\section{Diagnosis in the Carakasamnitāa: Authoritative Testimony and the Physician's Sensory Perceptions}

In the Carakasaṃhitāa a compendium that predates the Aștāngahrdayasaṃitā by several centuries, instructions for diagnosis are dispersed in various sections of the treatise, particularly in the Sütrasthāna, Nidānasthāna, and Vimānasthāna. Here, I focus on two passages that lay out the epistemological foundation for diagnosis in the text: Carakasaṃhitā, Sütrasthāna 11.17-25 and Vimānasthāna 4.1-7. Both of these passages detail the relationship between authoritative teaching and sensory perception as pramānas, means of valid knowledge, and therefore as the basis for diagnosis. As Karin Preisendanz notes in her detailed analysis of eristics and epistemology in the Carakasamnhitā in comparison with the Nyāyasūtra, ${ }^{46}$ these sections articulate two epistemological models. The first model comprises authoritative teaching (äptopadeśa), sensory perception (pratyakșa), ${ }^{47}$ inference (anumāna), and conjunctive reasoning (yukti), and the second model comprises the first three of the pramānas listed above, excluding yukti. ${ }^{48}$ While authoritative teaching, perception, and inference are considered distinct pramānas in other Indian philosophical systems, yukti is regarded as a separate form of reasoning only in Ayurveda (Dasgupta, Agarwal, and Jain 1969, 2:375; Filliozat 1990, 33; Preisendanz 2009, 281 ). We will examine these passages, paying close attention to the representation of the physician's senses in relation to authoritative teaching, and in

46 Akșapāda's Nyāyasūtra is the foundational work of Nyāyaśāstra, a classical philosophical school of logic. See Preisendanz 2009, 262.

47 Sensory perception as a pramāna in the Carakasamhitā is based upon the five sense cognitions (pañcendriyabuddhis): sight-cognition (cakșurbuddhi), hearing-cognition (śrotrabuddhi), smell-cognition (ghrānabuddhi), taste-cognition (rasanabuddhi) and touch-cognition (sparśanabuddhi). These five sense cognitions are explained in Sütrasthāna chapter eight, as a conglomeration of the five sense faculties (pañcendriya), their five material bases (pañcendriyadravya), the five sense organs (pañcendriyādhișthāna), and the five sense objects (pañcendriyārtha), motivated by the mind (sattva) in conjunction with the Self (ätman) (Carakasaṃhitā, Sūtrasthāna 8.7-12). In this interaction producing sensory perception, mind, the "cause of the senses" (pratyayabhütam indriyānāam), is the key motivator of the sense faculties. Cakrapānidatta glosses pratyayabhütam as kāranabhütam, in reference to the mind, literally "being the cause of the senses" (Carakasaṃhitā, Sūtrasthāna 8.7).

48 Preisendanz's (2009, 287-288) detailed analysis ultimately reveals three epistemological models in the Carakasamnitā: the two discussed here, and a third, derived from Vimānasthāna 8.27 and 8.33 resembling Nyāyasūtra 1.1.3. 
consultation with the eleventh-century medical writer Cakrapānidatta's commentary, the Âyurvedadīpikā.

The description of the pramānas given in Carakasaṃhitā, Sütrasthāna 11.17-11.25 foregrounds a discussion of the authoritative individual, and is found in the context of an explanation of how one can know the existence of the world-beyond (paraloka) in relation to the three desires motivating a human life: "desire for life" (prāṇaișanāa), "desire for wealth" (dhanaișaṇā), and "desire for the other-world" (paralokaișaṇā). ${ }^{49}$

\section{Carakasaṃhitā, Sūtrasthāna 11.17-11.25:}

11.17 Everything is twofold, indeed, existent (sat) and nonexistent (asat). ${ }^{50}$ Its fourfold examination (parīkșa $)$ is [known as] authoritative teaching, sensory perception, inference, and reasoning. ${ }^{51}$

11.18-19 First, the authoritative ones ( $\bar{a} p t a)$ : Those who are completely free from passion (rajas) and inertia (tamas) by means of the strength of spiritual endeavor (tapas) and knowledge ( jĩanna), who always possess clear unimpeded knowledge of the past, present, and future; those learned (śișta), enlightened (vibuddha) authorities; their speech is, without a doubt, true. Those who are completely free from passion (nirajastama), how could they speak the untruth?52

11.20 The cognition (buddhi) which is manifest in the present [and] arises due to the conjunction of Self (ätman), ${ }^{53}$ sense faculties (indriya),

Carakasaṃhitā Sūtrasthāna 11.3. As Pierre-Sylvain Filliozat notes, Cakrapāṇidatta assimilates this triad to the trivarga, the set of three of the purușārthas (human-goals)—dhar$m a$ (righteous conduct), artha (wealth), and kāma (pleasure). See Filliozat 1993, 96-97; 2006, 1971-1972. For a detailed discussion of the meaning of paraloka and paralokaișana in this context, see Preisendanz 2009, 280, 298nn79, 82, 83, and 84 .

50 Here I follow Preisendanz's (2009, 280) translation of sat and asat as "existent" and "inexistent."

$5^{1}$ dvividham evakhalu sarvam sac cāsac ca tasya caturvidhā parīkṣāāptopadeśah pratyakṣam anumānam yuktiś ceti //

$5^{2}$ āptās tāvat // rajastamobhyām nirmuktās tapojñānabalena ye / yeșām trikālam amalạ̣ jñānam avyāhatạ̣ sadā // āptāḥ śișțā vibuddhāste teșām vākyam asaṃśayam/ satyam vakșanti te kasmād asatyam nìrajastamāh //

53 Antonella Comba $(1987,48-49)$ shows that the term buddhi can be understood in different passages of the Carakasamnitā through the lens of Sāmkhya philosophy, as a faculty of intellect, or through the lens of Vaiśeșika philosophy, as "knowledge' or 'cognition' which is understood as a quality or property (guna) of the ätman [Self], and is one of the signs from which its existence can be inferred." In this passage I translate buddhi in the Vaiśeșika sense, as it is a cognition that corresponds to both inference and reasoning in Sūtrasthāna 11.22 and 11.25, respectively. Cf. Filliozat 1967, 1967nı. 
mind (manas), and sense objects (artha), is known as sensory perception (pratyakșa). ${ }^{54}$

11.21-22 [Inference] is preceded by perception, it is threefold, and relates to the past; present, and future. Hidden fire is inferred from smoke; sexual intercourse is inferred because of seeing pregnancy (garbha) - in this way, wise men ascertain the past; they ascertain future fruit from a seed, having seen here that from a seed a fruit of the same kind arises. ${ }^{55}$

11.23-24 From the conjunction of water, ploughing, seed, and season, grain arises. In this way, the fetus arises from the conjunction of the six elements (dhātu), [this is] conjunctive reasoning $(y u k t i)$. Fire arises from the conjunction of the fire-kindler (mathya), kindling wood (manthana), and the person churning (manthana). The application of conjunctive reasoning (yukti), in relation to the excellence of the "four pillars," ${ }^{2}$ destroys disease.

11.25 Conjunctive reasoning (yukti) is that cognition (buddhi) which recognizes existence arisen from the conjunction of many causes. It is to be understood as referring to the three [modes of] time. In which manner, "three aims of life" (trivarga) are accomplished by it. ${ }^{57}$

54 àtmendriyamanorthānām sannikarșāt pravartate / vyaktā tadātve yā buddhih pratyakṣaṃ sā nirucyate//

55 pratyakșapūrvaṃ trividhaṃ trikālaṃ cānumìyate / vahnir nigūụho dhūmena maithunạ̣ garbhadarśanāt // evaṃ vyavasyanty atītaṃ büjät phalam anāgatam / drșțāa bïjāt phalaṃ jātam ihaiva sadrísam budhāḥ //

${ }_{5} 6$ Carakasaṃhitā, Sūtrasthāna, chap. 9, describes the "four pillars" (catușpāda) of Ayurveda as the physician, medicine, attendant, and patient. jalakarșanabijartusaṃyogāt sasyasaṃbhavaḥ / yuktị̣ șaḍhhātusaṃyogād garbhāṇām saṃbhavas tathā // mathyamanthana(ka)manthānasaṃyogād agnisaṃbhavah /yuktiyuktā catuṣpādasampad vyādhinibarhaṇi // Gañgādhara's succinct reading clarifies the passage. He explains, " $m a$ thya' is the wood-piece situated below which has the purpose of churning, called the 'arani,' 'manthana' is the wood-piece situated above, with which the arani, is rubbed, 'manthāna' is the person churning (lit. the 'churner')." mathyamanthanamanthānasamyogād agnisambhavah / mathyam manthanārtham adhaḥsthakāștham araṇir nāma manthanam ürddhvasthakāṣțham yena ghrșyati manthānaḥ kartā eșām saṃyogān manthanakriyayāvaśyam agnisambhava iti bhavișyantī yuktį̣ / See Gangādhara's Jalpakalpatāru, 1:541. For a thorough discussion of the four pillars of treatment as they are explained across a range of Ayurvedic texts, see Wujastyk 2012, 26-67.

57 Gangādhara explains trivarga in this passage as the set of three of the purușārthas (human-goals)—dharma (righteous conduct), artha (wealth), and kāma (pleasure). Gangādhara's Jalpakalpatāru, 1:541. buddhị paśyati yā bhāvān bahukāraṇayogajān / yuktis trikālā sā jñeyā trivargaḥ sādhyate yayā / eșā parīkșā nāstyanyā yayā sarvam parīkṣyate / parīksyam sad asac caivam tayā cāsti punarbhavaḥ // 
In explaining the pramānas, this passage foregrounds the importance of authoritative teaching by describing the qualities of the authoritative person (apta) at the outset. The authoritative person, who is capable of authoritative teaching (āptopadeśa) or authoritative speech (äptavacana), must achieve a state free from the doșas of the mind, passion (rajas) and inertia (tamas). ${ }^{58}$ This is accomplished through the practice of tapas, which can be translated as austerities, "penance" (Meulenbeld 1999, 1A:59), or "spiritual endeavor" (Ashokan 2015, 194) in order to achieve an idealized state of knowledge pertaining to the past, present, and future. Next, the passage describes sensory perception as a form of cognition (buddhi) that takes place in the present moment, involving the Self (ätman), sense organs (indriyas), mind (manas), and sense objects (arthas). The apta is one whose mind is free from doșas, and the teaching of an apta is infallible in contrast to the sensory perception of a non-äpta. For the practitioner engaging with the text of the Carakasamnhitā, the source of authoritative teaching is not only the guru, or teacher, but also the treatise itself, presumably reflecting the a $\bar{p} t a$ status of its authors. The sensory perceptual capacities of practitioners are understood as built upon their relationship to authoritative teaching, and without its basis, the physician cannot perceive clearly and thereby cannot infer or reason accurately. Whereas the a $\bar{a} t a$ is believed to perceive the past, present, and future, the physician must combine sensory observation with inference and/or reasoning, in order to understand the unfolding of a disease and to diagnose. G. Ashokan (2015, 194) contrasts the primacy of authoritative teaching in Ayurveda with other philosophical systems, explaining that "in Ayurveda scriptural knowledge is an essential prerequisite for a physician. It is only after attaining competency in scriptural testimony that a physician becomes proficient in making use of the other sources of knowledge for diagnosis." Although the knowledge attained by an authoritative individual through the practice of tapas may come to them through insight or revelation, their presumed clarity of mind also suggests that they have special sensory perceptive capacities, serving as an ideal toward which the physician should strive.

The relationship between authoritative teaching and the sensory perceptual capacity of the physician is further explored in a passage explaining the mechanisms of diagnosis, Carakasaṃhitā, Vimānasthāna, chapter 4. Vimāna means "evaluation"59 and the chapters of the Carakasamnhitā, Vimānasthāna explain,

$5^{8}$ In Carakasamnitā Sūtrasthāna 1.57, rajas and tamas are explained as the two doșas of the mind, along with the three doșas of the body.

59 In a paper given at the International Congress on Traditional Asian Medicines, August 9, 2017, Dominik Wujastyk argued that in the Carakasaṃhitā, the term vimāna is to be 
in succession, the viśeșas (specific characteristics, distinctions, or properties) of the six flavors, stomach capacity, epidemics, and in the fourth chapter, diseases (there are eight chapters total). This section of the compendium also emphasizes the fundamental place held by authoritative teaching, defining its characteristics and relationship to the other pramannas. Cakrapānidatta emphasizes this in his commentary on Vimānasthāna 4.5, explaining that just as a person with no training cannot see the differences and specificities of types of jewels, neither can the physician assess a disease through sensory perception and inference without a foundation of authoritative teaching. ${ }^{60}$ Here, I include only the discussion of authoritative teaching and sensory perception, along with an excerpt from Cakrapānidatta's clarifying discussion of the way that these pramānas function for a physician.

\section{Carakasaṃhitā, Vimānasthāna 4.1-4.7:}

4.1-2 Now we will explain the evaluation (vimāna) that is to be understood as the threefold knowledge of the distinguishing properties of diseases, said venerable Âtreya. ${ }^{61}$

4.3 Indeed there is threefold knowledge of the distinguishing properties of diseases, namely, authoritative teaching, perception, and inference. ${ }^{62}$

4.4 In that context, authoritative teaching is called "the speech of an authority" (äptavacana), because, indeed, authoritative people possess knowledge without doubt (vitarka), without [reliance on] memory $(s m r t i),{ }^{63}$ or without incompleteness (vibhäga), ${ }^{64}$ and without attachment or hatred. Their speech is a valid means of knowledge (pramāna)

understood as deriving from a verbal root $\sqrt{m} \bar{a}$, meaning "ascertain." Wujastyk's convincing argument, based on both Cakrapānidatta's commentary and a paper by Thomas Burrow (1980), goes against the conventional translation of vimāna as "measurement" derived from the verbal root $\sqrt{m a}$ meaning "measure."

6o anupadeśavāṃs tān upalabhamāno 'pi hetvādiviśeșān aśikṣitaratnaparīkṣo yathā ratnānāṃ viśeșam paśyann api nāvadhārayati ratnaviśeșaṃ tathā nāvadhārayati vyādhiviśeșam iti bhāvah /

61 athātas trividharogaviśeșavijñānīyaṃ vimānaṃ vyākhyasyāmah // iti ha smāha bhagavān ätreyah //

62 trividham khalu rogaviśeșavijñānam bhavati tad yathā āptopadeśah pratyakṣam anumānam ceti //

63 According to Cakrapānidatta, smrtijñāna means knowledge that is learned from others, through commonly held beliefs or teachings, rather than through firsthand experience (anubhava). He cites the examples of "knowledge arisen from traditional teachings and knowledge of calculation" (smrtiśāstrajam jñānam gaṇitajñānam ca). vibhāga is glossed by Cakrapānidatta as ekadeśah, "part of the whole." 
because they possess such qualities. On the other hand, an invalid means of knowledge (apramanna) is the speech of an intoxicated person (matta), a mentally unstable person (unmatta), a fool (mürkha), an impassioned person (rakta), and a person of mixed character (duștādușța). And indeed, sensory perception (pratyakșa) is accomplished by the Self with the sense faculties and mind. Indeed, inference (anumāna) is speculation (tarka) based on conjunctive reasoning $(y u k t i) .65$

4.5 Having first examined the disease, fully, by this threefold valid means of knowledge (jñānasamudāya) ${ }^{66}$ everything he determines later [will be] faultless. Indeed, knowledge of that which is to be understood completely is not produced through partial knowledge. In reference to this threefold collection of pramānas, there is prior knowledge because of authoritative teaching. Then, examination (parīkșā) takes place through perception (pratyakșa) and inference (anumāna). Indeed, what that has not been previously taught can be known by being examined though perception and inference? Because of this, the twofold examination [undertaken by] those possessing knowledge is perception and inference, or threefold with [authoritative] teaching. ${ }^{67}$

Cakrapānidatta: ... First, authoritative teaching makes one understand the disease, and then the disease explained by the apta is determined through perception and inference by means of examining the symptoms, etc., as mentioned. When there is a disease that is not taught through the doctrine, like a non-physician (avaidya), one (the physician) [is not able to] diagnose that disease through perception and inference. Thus it is said ... "or threefold" (trividh $\bar{a} v \bar{a}$ ) means at the time of examination of

65 tatrāptopadeśo nāmāptavacanam / āptā hy avitarkasmṛtivibhāgavido nișprītyupatāpadarśinaś ca / teșām evaṃnunayogād yad vacanam tat pramānam / apramāṇạ̣ punar mattonmattamūrkharaktāduștavacanam iti pratyakșaṃ tu khalu tad yat svayamindriyair manasā copalabhyate / anumānam khalu tarko yuktyapekșah // Cakrapāṇdatta's gloss suggests that svayam indriyaih is to be understood as ätmanā indriyaih, "by the sense faculties with the Self." svayam indriyair manasā cety anena yad ātmanendriyaiś cakșurādibhir avyavadhānena gṛhyate rūpādi tat pratyakșam iti. In this passage, yukti is understood as a component of anumāna rather than as a separate pramāna.

66 Cakrapāṇidatta glosses jñānasamudāyah as pramānasañghātah, "collection of valid means of knowledge." So, here, I translate jñāna as pramāna.

67 trividhena khalv anena jñānasamudāyena pürvam parīkșa rogạ̣ sarvathā sarvam athottarakālam adhyavasānam adoșaṃ bhavati na hi jñānāvayavena krtsne jñeye jñānam utpadyate / trividhe tv asmin jñānasamudaye pūrvam āptopadeśāj jñānam tatah pratyakșānumānābhyām parīkșopapadyate / kị̣ hy anupadiștạn pūrvaṃ yat tat pratyakșānumānābhyām parīkșamāṇo vidyāt / tasmād dvividhā parīkșā jñānavatām pratyakșam anumānam ca trividhā vā sahopadeśena // 
the disease, indeed, authoritative teaching is also used in reference to understanding weakness of the duodenum (grahanimārrdava) ${ }^{68}$ or dreams, [and also] knowledge of a difficult-to-assess location [of disease], etc. In this manner, "authoritative teaching" in the form of the speech of the sick person is also applied to the examination of softness or hardness of stools, etc. This is shown. ${ }^{69}$

4.6 In reference to this, wise ones explain each and every disease [based upon] the type of aggravation (prakopana), origin (yoni), cause (utthāna), nature (ātman), site (adhișthāna), suffering (vedana), symptom (samsthāna), sound-touch-appearance-taste-smell (śabdasparśarūparasagandha), complication (upadrava), association with increase, stasis, and decrease (vrrddhisthānakșayasamanvita), outcome (udarka), naming (nāmāna), application (yoga); in reference to that (particular disease), it is known through [authoritative] teaching (upadeśa), "for the purposes of cure, this is prescription or this is prohibition." ${ }^{70}$

4.7 But, indeed, the one desiring to know the essence of the disease directly, should examine all of the sense objects in relation to the body of the patient, with all of [their] senses, except with the knowledge of taste

68 Grahañi refers to a location in the digestive tract that is between the umbilicus (nābhi) and stomach (amaśaya) and also to the malabsorption of food in this location due to weak digestive fire (agni). At issue here is the physician's ability to differentiate between different types of bowel disorders: grahañi, characterized by frequent loose stools containing undigested or partly digested food; atisāra, characterized by loose stools with excess fluid; and arśas, piles, characterized by frequency of stools. Here, Cakrapānidatta is arguing for authoritative teaching as the foundation of differential diagnosis, a process by which the physician uses comparison and elimination to determine the nature of the disease. Thanks to M. K. Madan Kumar for clarifying this point. See Carakasaṃhitā, Cikitsāsthāna $15 \cdot 5^{6-57}$.

69 prathamāptopadeśo vyādhim bodhayati tataś cāptopadiștạn vyādhị̣ pratyakșānumānābhyām yathoktalingādiparīkșyā niścinoti āgamānupadiște ca vyādhau avaidya iva na pratyakșeñānumānena ca vyādhim upalabhata ityāha ... trividhā vety anena vyādhiparīkșāsamaye hy āptopadeśo'pi vyāpriyate grahan̄imārdavasva pnadarśanādipratipattau tathā duradhigamasthānasaṃśrayādipratipattau tathā koșthamrịdudārunatvādiparīkșāyām cāturavacanarūpāptopadeśo 'pi vyāpriyata iti darśayati / I am reading prathamam āptopadeśo rather than prathamāptopadeśo as this makes more sense in the context of the commentary.

70 tatredam upadiśanti buddhimantah / rogam ekaikam evamprakopaṇam evamyonim evamutthānam evamātmānam evamadhișthānam evaṃvedanam evamsaṃsthānam evamśabdasparśarūparasagandham evamupadravam evaṃvrddhisthānakșayasamanvitam evamudarkam evamnnāmānam evaṃyogam vidyāt tasminn ìam pratīkārārthā pravṛttir athavā nivrttir ity upadeśāj jñāyate // 
(rasa). In this manner, one should examine through hearing: gurgling of the bowels (antraküjana), cracking of the joints (sandhisphuțana) and finger joints (anguliparvan), and characteristics of the voice (svaraviśeșa). If there are other sounds emanating from somewhere in the body one should also examine [them] through hearing. One should examine through sight: color (varna), appearance (samsthāna), measurement (pramāna), complexion, natural or changed state of the body, [and] those things related to vision that are unmentioned. And indeed one should also understand, through inference, taste inside of the body of the patient, related to the [taste] sense faculty (indriya). Indeed, one does not obtain the understanding of this through sensory perception. Therefore, one should only understand the taste in the mouth of the patient by questioning the patient. Thereby [one should understand] the bad taste of [the patient's] body by a louse moving away [from it], the sweetness of the body, through flies moving toward [it]. Regarding doubts about [the nature of] pitta in the blood [one should understand] what is called "healthy blood" (dhārilohita) or "bile-blood" (lohitapitta). ${ }^{71}$ Due to consumption by a dog or crow "healthy blood" is to be inferred; from their not consuming [it], "bile-blood" is to be inferred. Thus, [the physician] should also infer other flavors that are related to the body of the patient. But indeed, one should examine by smell the natural or changed state of odors related to the patient's whole body. And one should examine by hand the natural or altered state of touch (sparśa) [of the patient]. Examination through perception, inference, and authoritative teaching is thus explained. ${ }^{72}$

71 Cakrapānidatta explains dhärilohitam as jīvaśonitam, in the sense of vital or healthy blood and lohitapittam as pittadustam, blood "corrupted by pitta" in the sense of raktapittam, "bile-blood."

72 pratyakșatas tu khalu rogatattvam bubhutsụ sarvair indriyaị sarvān indriyārthān āturaśarīragatān parīkșeta anyatra rasajñānāt tad yathā antrakūjanam sandhisphuțanam añgulīparvaṇām ca svaraviśeșāṃś ca ye cānye 'pi kecic charīropagatāh śabdāh syu[s] tāñ chrotreṇa parīkṣeta varṇasaṃsthānapramāṇacchāyāḥ śarīraprakrtivikārau cakṣurvaișayikāṇi yāni cānyānyanuktāni tāni cakșuṣā parīkșeta rasạ̣ tu khalv àturaśarīragatam indriyavaișayikam apy anumānād avagacchet na hy asya pratyakșeṇa grahaṇam upapadyate tasmād āturaparipraśnenaivāturamukharasam vidyāt yūkāpasarpaṇena tv asya śarīravairasyam makṣikopasarpaṇena śarīramādhuryam lohitapittasaṃdehe tu kị̣ dhārilohitam lohitapittam veti śvakākabhakṣaṇād dhārilohitam abhakșaṇāl lohitapittam ity anumātaryam evam anyān apy āturaśarīragatān rasān anumimìta gandhāms tu khalu sarvaśarīragatānāturasya prakrtivaikārikān ghrānenena 
This passage begins by explaining in detail the qualities of authoritative teaching (4.4) and proceeds to establish authoritative teaching as the basis for sensory perception and inference (4.5) in the physician's diagnostic process. First, one must have prior knowledge of the disease and, only then, observe the patient. Through the use of sight, smell, touch, and hearing - in this case, hearing the sounds emanating from the body of the patient rather than their words - the physician's body is deeply implicated in the process of diagnosis. Sense perception enables the physician to identify and differentiate the sense objects reflected in the disease. Karin Preisendanz notes that at the end of Vimānasthāna 4.5 there appears to be a shift toward prioritization of sensory perception that is also reflected in the order presented at the end of Vimānasthāna 4.7. She argues that this may reflect a relationship with Nyāya philosophy, which recognizes sensory perception as the basis for valid knowlege (Preisendanz 2009, 286-288). Her detailed analysis is based upon over fifty manuscripts collected as part of a project compiling a critical edition of the Carakasamnitā Vimānasthāna and reflects an understanding of the layers in the text and variant attestations of the treatise. Here, the mention of a "twofold examination" consisting of sensory perception and inference, or "threefold" with authoritative teaching listed third, presents a reordering of the importance of the pramannas with authoritative teaching as an adjunct to sensory perception and inference. However, it is notable that these enumerations are immediately preceded by a question prioritizing authoritative teaching: "Indeed, what that has not been previously taught can be known by being examined though perception and inference?" The passage also specifies that the twofold examination is to be employed by "those possessing knowledge," which I interpret as referring to those who have already received authoritative testimony, indicating that the implicit basis of authoritative teaching remains present. Those who are not already posessing knowledge should count authoritative teaching among the set of three. ${ }^{73}$ Cakrapānidatta's commentary

parīkșeta sparśam ca pāninā prakrtivikrtiyuktam / iti pratyakșato anumānād upadeśataś ca parīkșanam uktam //

There are other passages in the Carakasamhitā that do not foreground authoritative testimony. For example, Vimānasthāna, chap. 8, examined in detail by Preisendanz via the critical edition of this chapter (not yet published). In the Indriyasthāna, a section of the treatise dealing with signs of impending death, there are two categories of signs, those residing in the patient (purușasamśraya) and those not dependent upon the patient (purușam anāśrita). In order to examine the first category, which includes the patient's complexion and sounds emanating from the body, sensory perception is the most important pramāna. In reference to the second category, including omens, authoritative teaching and reasoning are most important. Also, a different set of 
on Vimānasthāna 4.5 also strongly emphasizes the primacy of authoritative teaching in the diagnostic process, but he also states that the patient's description of certain symptoms that cannot be directly observed by the physician qualify as a form of authoritative teaching. Although this may challenge the description of âpta found in chapter 11 of Sütrasthāna, it is consistent with the importance of questioning the patient in the threefold model for applied diagnosis found in Carakasaṃhitā, Cikitsāsthāna $25 \cdot 22,{ }^{74}$ a passage that, much like Aștāingahṛdayasaṃhitā, Sütrasthāna 1.22, prescribes sight, questioning, and touch for diagnosis, and was likely the source for the latter.

These passages may evidence a reduction, over the course of time, in the number of senses that the physician was expected to use in the course of diagnosis from four to three. ${ }^{75}$ Chapter 4 of Carakasam hitā, Vimānasthāna instructs the physician to use all of his senses with the exception of taste ( $r a s a$ ) because for something to be tasted, it must enter the taster's body. Rather, the patient's taste is inferred through the behavior of insects based on their taste faculties. In the Carakasamnhitā, Cikitsāsthāna 25.22 and the Aștāngahridayasaṃhitā, Sütrasthāna 1.22 we find only the senses of seeing, touch, and hearing prescribed as diagnostic tools, leaving aside both taste and smell. Carakasaṃhitā, Cikitsāsthāna 25.22 is found in a section of the Carakasamnhitā that may have been written by Dṛ̣̂habala in the fourth or fifth century, rendering it a later addition to the treatise, ${ }^{76}$ and the Asțāngahrdayasaṃhitā was written in the seventh century. The removal of smell from the list in the later passages perhaps

four valid means of knowledge is presented in Suśrutasaṃitā, Sūtrasthāna 1.16: sensory perception (pratyakșa), authoritative teaching (ägama), inference (anumāna), and analogy (upamāna). As Preisendanz $(2009,289)$ notes, the editor provides an alternate reading placing authoritative teaching first, however, the commentator Dalhana gives priority to sensory examination in his gloss of the passage.

74 "Examination is said to be (lit. remembered) threefold, by means of seeing, questioning, and touch; [examination] of age, coloration, body, and sense faculties [is to be made] by means of seeing, the wise ones should examine pain, habit, and strength of digestive fire through questioning, softness and coldness with their opposites should be examined by means of touch." darśanapraśnasamsparśaih parīkṣā trividhā smṛtā / vayovarṇaśarīrāṇām indriyānāạn ca darśanāt // hetvartisātmyāgnibalam parīkṣam vacanād buddhaih / sparśān mārdavaśaitye ca parīkṣye saviparyaye // In this passage, touch is listed last, in contrast to the similar, and chronologically later passage, in the Aștāingahrdayasaṃhitā, Sütrasthāna 1.22 where the order is seeing, touch, and questioning.

75 Thanks to Dominik Wujastyk for encouraging me to pursue the issue of chronology further in my forthcoming dissertation.

76 According to Meulenbeld's (1999, 1A:131) careful discussion of the matter, out of the seventeen chapters attributed to Dṛ̣habala, the seventeenth is either the twenty-third or the twenty-fifth chapter of the Carakasamnhitā. The colophon of the twenty-fifth chapter states 
reflects an increasing sensitivity to the boundaries of the physician's body in the course of diagnostic practice. It is worth noting that according to the surgical school of medicine, not addressed here, in Suśrutasaṃhitā, Sütrasthāna 10.5, a sixfold method of diagnosis via the five sense organs (srotases) and questioning (praśna) is given, in explicit contrast to the threefold method. This complicates a chronological hypothesis becasue the Suśrutasaṃhitā predates Văgbhața's compendia and it supports the possibility that surgical physicians may have had distinct social status and a different relationship to the senses in diagnosis. ${ }^{77}$

\section{Diagnosis as Sensory Negotiation}

Authoritative teaching is a foundation of classical Ayurvedic epistemology according to the Carakasamhitā, and by extension, of diagnosis. Successful processing and assimilation of sensory perception through inference and reasoning rests upon this foundation of authority in the form of treatise and guru. As physicians negotiate between Ayurvedic epistemologies and contemporary medical epistemologies, a sensory negotiation takes place that impacts their embodied experience of diagnosis and treatment. This negotiation is not only between the authoritative teaching of texts and teachers juxtaposed, in the course of practice, with diagnostic imaging and laboratory tests, but also involves physicians' aspirations toward an idealized sensory state. In conversations and interviews two main themes arose that, I suggest, relate to this experience: first, the issue of how contemporary diagnostic technologies and "modern" lifestyles impact physicians' sensory diagnostic capacities, particularly with relation to the mind, and second, the relationship between the apta and the contemporary physician. A comment from Dr. K. illuminates these intertwined concerns in terms of diagnosis:

We are not even 10 percent using our sense organs in diagnosis today. We are giving our diagnoses to machines. We used to touch to diagnose

that it is attributed to Dṛ̣habala, whereas commentators Jajjața and Cakrapāṇidatta both assign him authorship of the twenty-third chapter.

77 Also, see Meulenbeld 1999, 1B:323n108. The issues of purity, touch, social stratification, and the physical boundaries of physicians in different schools of early Ayurveda in relation to Ayurvedic epistemologies, diagnosis, and treatment will be discussed in my forthcoming dissertation. For discussions of the purity and social status of physicians, see Filliozat 1964; Chattopadhyaya 1977, 255; Zysk 2000, 22; Olivelle 2017. 
a fracture. Now we order a light study-X-ray. This is the shift between vaidyas and doctors. Why he is a vaidya and he is a doctor. The skill of a vaidya is the skill of how he is using his sense organs for diagnosis.

Here, we encounter the distinction between doctor and vaidya, usually a term indicating more respect and connection to tradition than "doctor" or "physician." This is a reversal of the hierarchy expressed in the 1946 pre-independence Bhore report which states that Ayurvedic practitioners must use the term "Vaidya," as a less prestigious designation than "Doctor," the latter reserved for "a registered medical practitioner in modern scientific medicine" (Wujastyk $2008,48)$. In this quote from Dr. K., however, a vaidya is an authoritative physician, an apta with idealized sensory diagnostic capacities. The implication in Dr. K's statement is not only that physicians today underutilize their senses due to the availability of technologies to look inside of the body, but also that this practice attenuates their skill. Vaidyas are aspirational and authoritative figures capable of skillfully engaging their senses in diagnosis. Doctors, however, use their senses in diagnosis through building on authoritative teachings, not only of the treatise and guru, but also on the authority generated by "modern" medical technologies.

These issues are foregrounded in two conversations I had that turned to the topic of pulse examination, nādīparīkșa . This technique became integrated into Ayurveda in the fourteenth century and is widely used today, regarded by many as the most powerful diagnostic tool available within the system. ${ }^{78}$ Sitting in his consultation room, Dr. R., a physician in his mid-thirties, explained why he uses allopathic diagnostic methods rather than pulse diagnosis:

If you are going to use your body as an instrument, as a tool, then you would need to live a life free from all other distractions and be fully focused. You have to be a siddha. Those things that we don't usually think of as vices, like TV and movies, they would be a distraction for someone trying to train themselves to read the pulse.

He spoke of one person he knew, now deceased, who read the pulse "very well," emphasizing that "it was his only focus." This physician did not watch television, go to movies, or give attention to anything "outside of his practice." Dr. R. made it clear that pulse diagnosis was only possible for a different type of physician than himself, who has attained the status of a siddha, one who has attained

${ }_{78}$ See Bruns 2010, 67-70; Zysk 2013, 184. Many physicians regarded nāạīparīkșā as present in the early classical Ayurvedic treatises. 
supranormal skills through practice or prayer. Dr. S., a physician in her forties who practices in her home and is retired from teaching at an Ayurvedic college, self-identified as a third-generation vaidya. She shared a similar description of her uncle, explaining, "He only uses pulse and refuses the information from diagnostic tests." Dr. S. contrasted this with Ayurvedic physicians who use MRI and other diagnostic technologies, stating that they were "like allopaths." Citing "darśana, sparśana, and praśna" from the Aștāingahridayasaṃhitā, she detailed her diagnostic process in relation to that of her uncle:

You look for symptoms and abnormalities. After that you touch, for example in the case of vidradhi, abscess, vrddhi, growth, gulma, any protuberance, and use these to determine whether the ailment is väta, pitta, or kapha jā (arisen). Pulse comes after praśna, it is the most important diagnostic tool in Ayurveda. My uncle can tell everything, and I can tell things like blood pressure, whether a woman is on her period ... and a few others, only. It is divine. Pulse diagnosis is handled by different people differently. It is learned through experience. You can do an extra three years at Ayurveda College or study with a guru to really practice it ... something accessible only to a person free from sensory and mental distractions.

Like Dr. R.'s view of his friend who was apt at pulse diagnosis, Dr. S. considered her uncle to be free from "sensory and mental distractions," performing a "divine" level of diagnosis, similar to the authoritative individual (apta) free from passion (rajas) and inertia (tamas) in the classical treatises. She views this form of authority as external to herself, and while this does not impede her practice of diagnosis, it limits the data that she can collect through her felt sense of pulse diagnosis.

Dr. D., a physician in her early thirties working at a small clinic, shared her personal story of being diagnosed with a serious illness and subsequently meeting her guru. Here I cite her at length speaking about his diagnostic capacities with a focus on seeing, darśana:

Nowadays darśana is when the person is sitting nearby or coming ... but we don't know how the ācäryas (teachers) might have written about darśana. I told you about that one day the patient was coming from the house. ${ }^{79}$ I don't know if in any text it is written, CT, MRI, as darśana. I'm not against this. Nowadays everyone is following this. We don't want the patient to think "This doctor doesn't know anything." Two generations 
earlier they were much [more] dedicated for this profession. Through their meditation or dedication they would know that someone was coming. They would be preparing the medicines before the patient is coming.... Especially for snakebite ... they would know the direction of the patient coming, preparing the antidote before the patient comes. The environment would show signs ... he says one person is coming and he will tell about them. Then in one-and-a-half hours they come.... He is a mind reading expert-he is a great doctor ... he would not use MRI, nothing.... I have personally met two gurus, vaidyas. These kinds of gurus we won't find in Government Ayurveda College, [not in] clinics, [they are] not the typical caste [doctors] but [they become doctors] out of their own wish. They are not greedy for money-only charge for medicine. Taking the rejected cases, the challenges. He has the courage. By sitting with him I too get courage.

In this discussion, Dr. D. does not object to understanding MRI or CT scanning as possible means to expand the physician's capacity for diagnostic vision (darśana). However, it is clear that from her perspective, her guru relies not only on his five senses, but also on his mind, conditioned through "dedication" and "meditation," and an idealized intuitive sense that comes through practice and moral character.

The physicians I met who experienced a gurukula style of Ayurvedic education system studied with their guru before, during, and after BAMs training. ${ }^{80}$ The most senior practitioner I interviewed, Dr. N., a physician in his sixties who runs his own Ayurvedic hospital and outpatient treatment center, identified as a vaidya. At the same time, he spoke of "old vaidyas," temporally removed from the present and possessing an even more idealized sensory capacity than himself. While Dr. N. experiences his senses as highly attuned, he was instructed by his guru to practice pulse examination for over two decades before using it as a basis for diagnosis. All of the physicians who mentioned pulse diagnosis noted that it is a perceptual skill refined through personal practice and requiring additional training from a guru beyond the BAMs curriculum. Dr. N. explained seeing, touching, and questioning in terms that reflect yoga philosophy, emphasizing the importance of meditation as a mechanism to expand the mind's perceptive capacity. The following are excerpts from one phase of a lengthy exposition:

8o For a study of the teacher-student relationsip and Ayurvedic training in the classical texts, see Preisendanz 2007. 
When we touch something, that gives the real feeling of life itself irrespective of the part we touch. Even if I touch your aura I can diagnose.... The next level is sounds. I can hear. My sounds and your sound can talk. This is not only praśna.... In terms of darśana, it relates to agni (digestive fire).... I'm touching epidermis. It is not deep. I can touch to majja (marrow), ${ }^{81}$ I can touch anywhere ... that level of touch can be developed, mainly through dhyanna (meditation).... If you have very good agni then darśana is different. You open the third eye and see. Close eyes and see. I can see what is happening in my home from here.... A vaidya could hear the carotid artery sound. You can hear it with a stethoscope making a sound and know that the person will get facial paralysis.... All [modern technologies] have actually killed the efficacy of our sense-organs. Old vaidyas can hear all sounds. How many sounds are coming from our body? Each and every cells are producing sounds. If we could hear them with internal ears.... What do you touch with? First of all the body, not only the hands, why not with the shoulder.... My mind can go into other systems easily, it can pierce into a system. This technique, allopathy is using in a minute quantity. Why do we go to an experienced doctor (vaidya)? He can see many things without an MRI or lab tests.... Usually people come with tests. Usually I don't send anyone [for lab tests], but we have to be in a system (i.e., coexisting and interacting with allopathy) gracefully and intellectually, we must be able to communicate.

Dr. N.'s discussion here touches on a number of the factors to be examined (pariksyabhāvas) by the physician in relation to the doșas, as explained in the Aștāngahrdayasaṃhitā, Sütrasthāna 12.67-68, such as tissues (dhātus) and waste products (malas) vitiated by the doșas (termed dūsyas), place (location of the patient) (deśa), season and time of day (kāla), digestive force (anala), nature or constitution (prakrti), age (vayas), quality of the mind (sattva), habit (sātmya), diet (āhara), and stage of the disease (avasthā). However, Dr. N.'s exposition foregrounds the importance of the trained sensory capacity of the physician, taking a number of these factors into account in relation to the physician rather than the patient, such as digestive fire (anala/agni), nature, habits, and especially, the quality of mind of the physician, potentially refined through meditation, describing these factors in relation to an idealized

$81 \quad$ Key to an Ayurvedic understanding of the body is the system of seven tissues (dhātus) as successive by-products of metabolism: rasa (chyle), rakta (blood), mamsa (flesh), medas (fat), asthi (bone), majjan (marrow), and śukra (reproductive tissue). 
authoritative individual ( $\bar{a} p t a)$. He articulates the crux of the sensory negotiation taking place, the need to "be in a system gracefully and intellectually" with allopathic medicine and with the idealized vaidya simultaneously.

\section{Conclusion}

Dr. N.'s mention of meditation for the cultivation of touch as a form of sensory and extrasensory perception provides a bridge between the physician and the apta through the promise of transformation offered by practice. This is a promise extended within the Caraksamhitā itself in a series of verses, Śärïrasthāna 1.137-155, translated and studied in detail by Dominik Wujastyk (2011b). Wujastyk shows that these verses offer an eightfold yogic path with Buddhist elements predating the well-known Yoga Sūtras of Patañjali. His translation of verse 142 reads, "Liberation comes from the absence of passion (rajas) and lethargy (tamas), due to the disappearance of potent karma. The disjunction from all conjunctions is called non-rebirth" (Wujastyk 2011b, 40). From Sütrasthāna 11.19 we know that the āpta is an individual with a mind free from passion and inertia/lethargy achieved through tapas, and Wujastyk's translation suggests tapas should not be understood in the sense of "austerities" or "penances," but rather as meditation, providing a mechanism for an individual to practice toward this idealized state.

Joseph Alter also argues that Ayurveda operates through an ontological framework in which there is a model of an unreachable "metaphysical fitness," a mode of "radical self improvement," toward a state of superhuman perfection (Alter et al. 1999, S44). The way that the contemporary Ayurvedic physicians I spoke with explained authoritative teaching in relation to the training and utilization of their own senses reflects this notion of striving toward an idealized state. But it also crystallizes that unreachable state as the foundation for all knowledge and medical practice. At stake in Ayurvedic physicians' choice of diagnostic techniques is their understanding of the nature of authoritative teaching in relation to their own sensory perceptive capacities. Whether a physician bases their diagnostic process on the epistemic virtues of classical treatises or a human guru, on that of diagnostic imaging and laboratory tests, or on some combination of these means of knowledge, reflects their own embodied epistemological position. This relationship to knowledge and the senses entails what I am calling a sensory negotiation, converging on the physician's body as a site for the making of truth claims, and for the practice and experience of Ayurvedic medicine. Perhaps in this space which entails both rooting 
and innovation — orientation toward the past and present — we can conceive of Ayurveda in India today not as in a state of crisis, but in a state of innovative evolution.

\section{References}

\section{English Sources}

Alter, Joseph S., F. Bray, A. Guha, P.C. Joshi, and C. Leslie. 1999. "Heaps of Health, Metaphysical Fitness: Ayurveda and the Ontology of Good Health in Medical Anthropology [and Comments and Reply]." Current Anthropology 40: S43-S66.

Ashokan, G. 2015. Philosophy of Carakasaṃhitā. New Delhi: New Bharatiya Book Corporation.

Bruns, Prudence. 2010. Nāḍìijñāna: The Crest Jewel of Āyurveda, A translation of six central texts and an examination of the sources, influence and development of Indian Pulse-diagnosis. Germany: vdm Verlag Dr. Müller.

Burrow, Thomas. 1980. "Sanskrit $m \bar{a}$ - 'to ascertain." Transactions of the Philological Society $78(1)$ : 134-140.

ccim. N.D. "Central Council of Indian Medicine New Delhi Syllabus of Ayurvedacharya (BAMS) Course 1st Professional.” http://www.ccimindia.org/downloads/UG\%20 Syllabus\%20Ayu.\%20Committee\%2ofinal.pdf (accessed May 28, 2016).

Cerulli, Anthony. 2009. "Āyurveda." In Brill's Encyclopedia of Hinduism, vol. 2, Texts, Rituals, Arts, and Concepts, edited by K.A. Jacobsen, H. Basu, A. Malinar, and V. Narayanan, 267-280. Leiden: Brill.

Chattopadhyaya, Debiprasad. 1977. Science and Society in Ancient India. Calcutta: Research India Publications.

Comba, Antonella. 1987. “Carakasaṃhitā Śārīrasthāna I and Vaiśeșika Philosophy." In Studies on Indian Medical History, Groningen Oriental Studies 2, edited by Gerrit Jan Meulenbeld and Dominik Wujastyk, 39-55. Groningen: Forsten.

Dasgupta, Surendranath, R.R. Agarwal, and S.K. Jain. 1969. History of Indian Philosophy. 1st ed. Allahabad: Kitab Mahal.

Daston, Lorraine, and Peter Galison. 2007. Objectivity. New York: Zone Books.

Filliozat, Jean. 1964. The Classical Doctrine of Indian Medicine, Its Origins and Its Greek Parallels. 1st English ed. Delhi: Munshiram Manoharlal.

Filliozat, Pierre-Sylvain. 1990. "Yukti, le Quatrième pramāṇa des Médecins (Caraksaṃhitā, Sūtrasthāna XI, 25)." Journal of the European Ayurvedic Society 1: 33-46.

Filliozat, Pierre-Sylvain. 1993. "Caraka's Proof of Rebirth." Journal of the European Ayurvedic Society 3: 94-111.

Filliozat, Pierre-Sylvain. 2006. "La Logique du Médecin selon la Carakasaṃhitā." Comptes rendus des séances de l'Académie des Inscriptions et Belles-Lettres 150 (4): 1961-1975. 
Foucault, Michel, Frédéric Gros, François Ewald, and Alessandro Fontana. 2005. The Hermeneutics of the Subject: Lectures at the Collège De France, 1981-1982. 1st ed. New York: Palgrave-Macmillan.

Khandpur, Sujay, Amit K. Malhotra, Vidhyut Bhatia, Subandhu Gupta, Vinod K. Sharma, Rakesh Mishra, and Narendra K. Arora. 2008. "Chronic Arsenic Toxicity from Āyurvedic Medicines.” International Journal of Dermatology 47 (6): 618-621.

Langford, Jean. 2002. Fluent Bodies: Āyurvedic Remedies for Postcolonial Imbalance. Durham, NC: Duke University Press.

Leslie, Charles. 1976. "The Ambiguities of Medical Revivalism in Modern India." In Asian Medical Systems: A Comparative Study, edited by Charles Leslie, 356-367. Berkeley: University of California Press.

Leslie, Charles. 1992. "Interpretations of Illness: Syncretism in Modern Āyurveda." In Paths to Asian Medical Knowledge, edited by Charles Leslie and Allan Young, 177-208. Berkeley: University of California Press.

Manohar, P. Ram. 2014. “Ayurvedic Education: Where to Go from Here?" Ancient Science of Life 33 (3): 143-145.

Meulenbeld, Gerrit Jan. 1999. A History of Indian Medical Literature. 5 vols. in 3. Groningen Oriental Studies 15. Groningen: E. Forsten.

Ministry of Ayush. 2002. "National Policy on Indian Systems of Medicine \& Homoeopathy-2002." http://ayush.gov.in/sites/default/files/7870046089-Ayush\%20 \%20n\%2opolicy\%2oISM\%20and\%2oH\%2oHomeopathy_o.pdf (accessed May 28, 2016).

Modi, Narendra. 2016. "Text of PM's speech at Vision Conclave at Global Ayurveda Festival." http://www.pmindia.gov.in/en/news_updates/text-of-pms-speech-at-vision -conclave-at-global-ayurveda-festival-kozhikode/ (last modified February 2, 2016).

Mukharji, Projit Bihari. 2016a. "Baidya-as-Technology: From Diagnosis to Pharmacy in a Bottle." In idem, Doctoring Traditions: Ayurveda, Small Technologies, and Braided Sciences, 227-256. Chicago: University of Chicago Press.

Mukharji, Projit Bihari. 2016b. Doctoring Traditions: Āyurveda, Small Technologies, and Braided Sciences. Chicago: University of Chicago Press.

Olivelle, Patrick. 2017. "The Medical Profession in Ancient India: Its Social, Religious, and Legal Status." eJournal of Indian Medicine 9: 1-21.

Preisendanz, Karin. 2007. "The Initiation of the Medical Student in Early Classical Ayurveda: Caraka's Treatment in Context." In Pramānakīrtih: Papers Dedicated to Ernst Steinkellner on the Occasion of His 7oth Birthday, edited by Birgit Kellner et al., Wiener Studien zur Tibetologie und Buddhismuskunde 70, 629-668. Vienna: Arbeitskreis für tibetische und buddhistische Studien, Universität Wien.

Preisendanz, Karin. 2009. "Logic, Debate and Epistemology in Ancient Indian Medicine and Philosophy — an Investigation." Indian Journal of History of Science 44: 261-312.

Rai, Vartika, Poonam Kakkar, Jyotsna Singh, Chetna Misra, Santosh Kumar, and Shanta Mehrotra. 2008. "Toxic Metals and Organochlorine Pesticides Residue in 
Single Herbal Drugs Used in Important Āyurvedic Formulation-'Dashmoola." Environmental Monitoring and Assessment 143 (2008): 273-277.

Ranade, Subhash, and Sachin Kuber. 2010. "Classfication of Clinical Examination." In Ayurvedic Clinical Diagnosis with Modern Perspective, 11-48. Delhi: Chaukhamba Sanskrit Pratisthan.

Sankaranarayana, Manoj. 2013. "Texts and Physicians in Keralan Ayurveda: The Case of the Rescue Clyster." In Medical Texts \& Manuscripts in Indian Cultural History, edited by Dominik Wujastyk, Anthony Michael Cerulli, and Karin Preisendanz, 195-219. New Delhi: Manohar.

Scharfe, Hartmut. 1999. "The Doctrine of the Three Humors in Traditional Indian Medicine and the Alleged Antiquity of Tamil Siddha Medicine." Journal of the American Oriental Society 119 (4): 602-629.

Sule, Manjiri, and Sirish Kavadi. 1993. "The Reality of Ayurveda Medical Practice with Some Perceptions from the Field." Foundation for Research in Community Health Newsletter 7 (5): 8-10.

Wujastyk, Dagmar. 2012. Well-Mannered Medicine: Medical Ethics and Etiquette in Classical Āyurveda. Oxford: Oxford University Press, 2012.

Wujastyk, Dominik. 1997. "Medicine in India." In Oriental Medicine: An Illustrated Guide to the Asian Arts of Healing, edited by Jan van Alphen and Anthony Aris, 1937. London: Serendia Publications.

Wujastyk, Dominik. 2008. "The Evolution of Indian Government Policy on Ayurveda in the Twentieth Century." In Modern and Global Ayurveda: Pluralism and Paradigms, edited by Dagmar Wujastyk and Frederick M. Smith, 43-76. Albany: sunY Press.

Wujastyk, Dominik. 2011a. "Medical Error and Medical Truth: The Placebo Effect and Room for Choice in Ayurveda." Health, Culture and Society 1 (1): 221-231.

Wujastyk, Dominik. 2011b. "The Path to Liberation through Yogic Mindfulness in Early Âyurveda." In Yoga in Practice, edited by David Gordon White, Princeton Readings in Religion, 31-42. Princeton, NJ: Princeton University Press.

Wujastyk, Dominik. 2017. "What is 'vimāna' in the Compendium of Caraka?" Paper given at the International Congress on Traditional Asian Medicines, Kiel, Germany. August 9.

Zysk, Kenneth G. 2000. Asceticism and Healing in Ancient India: Medicine in the Buddhist Monastery. New York: Oxford University Press.

Zysk, Kenneth G. 2009. "Sanskrit Commentaries on the Carakasamnitā with Special Reference to Jajjața's Nirantarapadaryākhyā." eJIM-eJournal of Indian Medicine 2 (3): 83-99.

Zysk, Kenneth G. 2013. "An Indologist Looks at Siddha Medicine in Tamilnadu." In Medical Texts and Manuscripts in Indian Cultural History, edited by Dominik Wujastyk, Anthony Michael Cerulli, and Karin Preisendanz, 181-194. Delhi: Manohar. 


\section{Malayalam Sources}

Thirumulpad, K. Raghavan. 2014. Ashtangasangraha Malayalam Commentary, Prakasika Vyakhya Moolasiddhantham. 2nd ed. Chalakudy: Prakashika.

Vaidyan, P.M. Govindan. 2015. Ashtāngahrudayam Sūtrasthānam. Kodalungallur: Devi Book Stall.

Vaidyar, M. Narayanan Vaidyar. 2010. Charaka Samhitha Nidanasthanam \& Vimanasthanam. Calicut: Redstar Offset Printers.

Vaidyar, M. Narayanan Vaidyar. 2011. Charaka Samhitha Sareerasthanam \& Indriyasthanam. Calicut: Redstar Offset Printers.

\section{Sanskrit Sources}

Aștāinga Samgraha of Vāgbhața: Text, English Translation, Notes, Indeces [Sic] Etc. 1995. Translated by K.R. Shrikanthamurthy. 3 vols. Jaikrishnadas Ayurveda Series. Varanasi: Chaukhambha Orientalia.

Aștāingahrdaya with the Commentaries 'Sarvāngasundarā' of Arunadatta and 'Āyurvedarasāyana' of Hemādri. 2012. Edited by K.R.S. Navare. Annotated by Aṇnā Moreśwar Kuṇṭe and Kṛṣna Rāmchandra Sāstrī. Kashi Sanskrit Series. Varanasi: Chaukhamba Sanskrit Sansthan.

Aștāingasamgrahah of Vāhața or Vṛddha Vāgbhata with the Śaśilekhā Sanskrit Commentary by Indu. 2012. Edited by Dr. Shivaprasad Sharma. Banaras Ayurveda Series. Varanasi: Chowkhamba Sanskrit Series Office.

Caraka-Samhitā by the Great Sage Bhagavata Agniveśa Thoroughly Revised by Maharși Caraka andDrụhabala with 'Āyurvedadīpika' Commentaries of Śrìmat Cakrapānidatta and 'Jalpakalpataru' Explanatory Notes and Annotations of Mahamahopādhyāya Śrī Gañgādhar Kaviratna Kavirāja. 2011. Edited and revised by Kaviraja Shree Narendranath Sengupta and Kaviraja Shree Balachandra Sengupta. 5 vols. New Delhi: Rashtriya Sanskrit Sansthan. Reprint of the 1985 edition.

Carakasaṃhitā, Śrīcakrapāṇidattaviracityā Ayurvedadīpikāryākhyayā Saṃvalitā. 2009. Edited by Vaidya Jadavaji Trikamji Ācārya. 5 th ed. Varanasi: Chaukhamba Orientalia. Reprint of the 1941 Bombay edition.

The Sushrutasamhitā of Sushruta with the Nibandhasangraha Commentary of Shree Dalhaṇācārya. 1931. Edited by Vaidya Jādavjī Trikamjī Ācārya. 2nd ed. Bombay: Nirṇayasāgar Press. 